\title{
KHẢO SÁT NỒNG Độ ACID URIC HUYẾT THANH Ở BỆNH NHÂN BỆNH THẬN MẠN GIAI ĐOẠN CUỐI
}

\section{TÓM TẮT}

Mục tiêu: Khảo sát nồng độ acid uric (AU) huyết thanh, tỷ lệ tăng $A U$ huyết thanh và các yếu tố liên quan đến tăng $A U$ huyết thanh ở bệnh nhân bệnh thân mạn giai đoạn cuối điều trị bảo tồn và chạy thận nhân tạo chu kỳ. Phương pháp nghiên cứu: Nghiên cứu mồ tả cắt ngang được thực hiên trên 60 bênh nhân bệnh thận mạn giai đoạn cuối (ESRD) điều trị bảo tồn và 60 bênh nhân ESR̉ chay thân nhân tao chu kỳ để khảo sát nồng độ $A U$ huyết thanh. Kết quả: Nồng đô AU huyết thanh nhóm bảo tồn là 490,0 $\pm 131,6 \mu \mathrm{mol} / \mathrm{L}$, nhóm chạy thận nhân tạo chu kỳ là

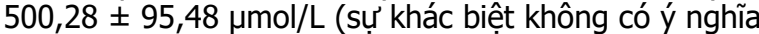
thống kê $(p>0,05)$. Tỷ ị̂ bệnh nhân ESRD có tăng AU huyết thanh là $85,0 \%$, trong đó nhóm điêu trị bảo tồn là $83,3 \%$ và ở nhóm chạy thận nhân tạo chu kỳ là $86,7 \%$ (sự khác biệt không có ý nghĩa thổng kê với $p$ $>0,05)$. Nồng độ AU huyết thanh tăng dân theo nhóm tuổi và nam giới cao hơn nữ giới trong nhóm bệnh nhân bệnh thận mạn điều trị bảo tồn $(p<0,05)$. Có mối tương quan thuận mức độ vừa giữa nồng độ $A U$ huyết thanh với chỉ số huyết áp tối đa $(r=0,423 ; p<$ $0,01)$ và huyết áp trung bình $(r=0,321 ; p<0,01)$. Không nhận thây mối tương quan giữa nồng độ $A U$ huyết thanh với chỉ số BMI và thời gian lọc máu. Kết luận: Nghiên cứu cho thấy nồng độ AU huyết thanh tăng cao ở nhóm bệnh nhân ESRD và có mối tương quan thuận giữa nồng độ $A U$ huyết thanh với chỉ số huyết áp.

Tư khóa: acid uric huyết thanh, ESRD

\section{SUMMARY}

SURVEYING THE CONCENTRATION OF SERUM URIC ACID IN PATIENS WITH ENDSTAGE RENAL DISEASE

Objectives: To investigate serum uric acid levels, the percentage of patients with increased serum uric acid and factors related to increased serum uric acid in patients with ESRD on conservative treatment and on hemodialysis. Methods: A cross-sectional descriptive study was performed on 60 patients with ESRD on conservative treatment and 60 patients with ESRD on hemodialysis to investigate the concentration of serum uric acid. Results: The concentration of serum uric acid in the group of patients with ESRD on conservative treatment was $490.0 \pm 131.6 \mu \mathrm{mol} / \mathrm{L}$, in the group of patients with ESRD on hemodialysis was $500.28 \pm 95.48 \mu \mathrm{mol} / \mathrm{L}$ (the difference was not

*Đại học Y khoa Vinh

Chịu trách nhiệm chính: Nguyễn Văn Tuấn

Email: tuanminh1975@gmail.com

Ngày nhận bài: 11.5.2021

Ngày phản biên khoa hoc: 25.6.2021

Ngày duyệt bài: 12.7.2021

\section{Nguyễn Văn Tuấn*}

statistically significant, $p>0,05)$. The proportion of patients with ESRD with increased serum uric acid was $85.0 \%$, in which the conservative treatment group was $83.3 \%$ and the hemodialysis group was $86.7 \%$ (the difference was not statistically significant, $p>$ 0.05). In the group of patients with ESRD on conservative treatment, the older the age was, the higher the serum uric acid concentration and uric acid levels are higher in men than in women $(p<0,05)$. There was a moderate positive correlation between serum uric acid concentration with maximum blood pressure index $(r=0.423 ; p<0.01)$ and mean blood pressure $(r=0.321 ; p<0.01)$. No correlation was found between serum uric acid levels with BMI and dialysis time. Conclusion: The study showed that the serum uric acid concentration was elevated in the group of ESRD patients and there was a positive correlation between the concentration of serum uric acid with blood pressure index.

Keywords: serum uric acid, ESRD

\section{I. ĐĂT VẤN ĐỀ}

Acid uric (AU) là sản phẩm chuyển hóa cuối cùng của purin và được đào thải qua thận $(60 \%$ - $70 \%$ ) và qua đường tiêu hóa $(30 \%-40 \%)$. Vì vậy suy giảm chức năng thận có liên quan đến tình trạng tăng acid uric huyết thanh, và $40 \%$ $80 \%$ bệnh nhân bệnh thận mạn giai đoạn cuối (ESRD) có tăng AỦ huyết thanh. Ở bệnh nhân lọc máu thì $A U$ được loại trừ một cách hiệu quả thông qua lọc máu. Điển hình, tăng $A U$ huyết thanh là dấu hiện của bênh gút. Hơn nữa, tác dụng bất lợi của chất này có liên quan đến sinh bểnh học của bệnh lý tim mạch và là nguyên nhân chính gây tử vong ở bệnh nhân lọc máu [7].

Mặc dù có đặc tính chống oxy hóa, AU cũng gây kích hoạt các con đường viêm trong cơ thể như NALP3, dẫn đến bài tiết interleukin-1 $\beta$ và các gốc oxy hóa. Ngoài ra, AU kích hoạt rối loạn chức năng nội mô và kích thích hệ thống renin-angiotensin-aldosterone, do đó góp phân vào sự phát triển của tế bào cơ trơn mạch máu và suy chức năng động mạch [2]. Để tìm hiểu sự thay đổi nồng độ $A U$ huyết thanh và các yếu tố ảnh hưởng đến sự thay đổi nồng độ $A U$ huyết thanh ở bệnh nhân ESRD điều trị bảo tồn và chạy thận nhân tạo chu kỳ, chúng tôi nghiên cứu đề tài này nhằm mục tiêu: Khảo sát nồng độ acid uric huyêt thanh, tỷ lệ tăng acid uric huyểt thanh và các yếu tố liên quan đến tăng acid uric huyêt thanh ở bênh nhân bênh thận mạn giai đoạn cuối điều trị bảo tồn và chạy thận nhân tạo chu kỳ. 
II. ĐỐI TƯỢNG VÀ PHƯƠNG PHÁP NGHIÊN CỨU

\section{1. Đối tượng nghiên cứu}

\subsubsection{Tiêu chuân lựa chọn}

- Bệnh nhân bệnh thận mạn giai đoạn 5 điêu trị bảo tồn và chạy thận nhân tạo chu kỳ tại Khoa Nội thận - Tiết niệu và lọc máu, Bệnh viện hữu nghị đa khoa Nghệ An.

- Tuối $\geq 18$ tuổi.

- Đồng ý tham gia nghiên cứu.

2.2.2. Tiêu chuẩn loại trừ. Bênh nhân bi bệnh thận mạn thứ phát do gút, đợt cấp bệnh thận mạn, nhiễm trùng cấp và mạn tính, sốt, chấn thương, phẫu thuật, ung thư.

\subsection{Phương pháp nghiên cứu}

2.2.1. Cỡ mấu và phương pháp chọn mẫu

- Cõ mẫu: 120 bênh nhân ESRD được đưa vào nghiên cứu, chia làm 2 nhóm:

+ Nhóm bệnh nhân ESRD điều trị bảo tồn: 60 bệnh nhân.

+ Nhóm bệnh nhân ESRD chạy thận nhân tạo chu kỳ: 60 bệnh nhân.

- Phương pháp chọn mẫu: Chọn mẫu thuận tiện những bệnh nhân thõa mãn tiêu chuẩn lựa chọn và tiêu chuẩn loai trừ?.

2.2.2. Thời gian và địa điểm nghiên cứu

- Thời gian nghiên cứu: Từ tháng 1/2021 đến hết tháng 5/2021

- Đia điểm nghiên cứu: Khoa Nôi thận tiết niệu - lọc máu, Bệnh viện hữu nghị đa khoa Nghê An.

2.2.3. Các tiêu chuẩn áp dụng trong nghiên cứu

2.2.3.1. Tiêu chuẩn chẩn đoán bệnh thận mạn và phân giai đoạn bệnh thận mạn

*Chẩn đoán bênh nhân bị bểnh thân man

Bệnh nhân được chẩn đoán xác định bi bênh thận mạn dựa vào tiêu chuẩn của Hội Thận họ Quốc gia Hoa Kyे - 2012 (NKF/KDIGO-2012) [6], gồm có:

- Có dấu hiệu tổn thương thận (kéo dài trên 3 tháng):

+ Albumin niêuu (albumin niệu $\geq 30 \mathrm{mg} / 24$ ).

+ Có hồng cầu niệu.

+ Các bất thường về điện giải do rối loạn chức năng ống thận.
+ Các bất thường được phát hiện qua khai thác tiền sử.

+ Các bất thường được phát hiện qua thăm khám siêu âm thận - tiết niêuu (hai thận kích thước có thể nhỏ hơn bình thường, nhu mô tăng âm, kém phân biệt tủy vỏ).

- Và / hoặc mức lọc cầu thận giảm dưới 60 $\mathrm{ml} / \mathrm{ph} / 1,73 \mathrm{~m}^{2}$ từ 3 tháng trở lên.

*Chẩn đoán giai đoạn bệnh thận mạn

Chẩn đoán giai đoạn bệnh thận mạn dựa vào MLCT ước tính. Trong nghiên cứu này chúng tôi ước tính MLCT dựa vào công thức CKD-EPI 2009 (Chronic Kidney Disease Epidemiology Collaboration - 2009). Theo Hội Thận học Quốc gia Hoa Kỳ - 2012 (NKF/KDIGO-2012), bệnh thận mạn được phân thành 5 giai đoạn dựa vào MLCT nhu' sau [6]:

Bảng 2.1. Phân giai đoạn bẹnh thận mạn theo NKF/KDIGO-2012

\begin{tabular}{|c|c|c|}
\hline $\begin{array}{c}\text { Giai } \\
\text { đoạn }\end{array}$ & Đánh giá & $\begin{array}{c}\text { MLCT } \\
\text { (ml/ph/1,73m²) }\end{array}$ \\
\hline 1 & $\begin{array}{c}\text { Mức lọc cầu thận } \\
\text { bình thường }\end{array}$ & $\geq 90$ \\
\hline 2 & $\begin{array}{c}\text { Mức lọc câuu thận } \\
\text { giảm nhẹ }\end{array}$ & $60-89$ \\
\hline 3 & $\begin{array}{c}\text { Mức looc cầu thận } \\
\text { giảm trung bình }\end{array}$ & $30-59$ \\
\hline 4 & $\begin{array}{c}\text { Mức lợc cầu thận } \\
\text { giảm nặng }\end{array}$ & $15-29$ \\
\hline 5 & $\begin{array}{c}\text { Mức lọc cầu thận } \\
\text { giảm rất nậng }\end{array}$ & $<15$ \\
\hline
\end{tabular}

2.2.3.2. Tiêu chuẩn chấn đoán tăng acid uric huyết thanh [1]

Tăng acid uric máu: acid uric máu $\geq 420 \mu \mathrm{mol} / \mathrm{I}$ đối với nam và $\geq 360$ mol//I đối với nữ.

Không tăng acid uric máu: acid uric máu < $420 \mu \mathrm{mol} / \mathrm{l}$ đối với nam và < 360 mol/l đối với nữ.

\subsection{Xử lý số liệu}

- Số liệu được xử lý bằng phần mềm SPSS 20.0.

- Sử dụng ANOVA test để so sánh trung bình các quan sát nếu biến có phân bố chuẩn.

- Sử dụng test X2 để so sánh sự khác biệt về tỷ lệ phần trăm.

- Sự khác biệt có ý nghĩa thống kê khi p < 0,05.

\section{KẾT QUẢ NGHIÊN CỨU}

Bảng 3.1. Đặc điểm tuổi và giới tính của đôi tượng nghiên cứu

\begin{tabular}{|c|c|c|c|c|c|c|c|}
\hline \multirow{2}{*}{$\begin{array}{c}\text { Nhóm } \\
\text { nghiên cứu }\end{array}$} & \multicolumn{2}{|c|}{ Chung } & \multicolumn{5}{|c|}{ Giới tính } \\
\cline { 2 - 8 } & $\mathbf{n}$ & Tuối(TB \pm SD) & $\mathbf{n}$ & Tuối $(T B \pm S D)$ & $\mathbf{n}$ & Tuối $(T B \pm$ SD) & p1 $^{*}$ \\
\hline $\begin{array}{c}\text { Nhóm ESRD điều trị } \\
\text { bảo tồn }\end{array}$ & 60 & $\begin{array}{c}53,73 \pm \\
17,57\end{array}$ & 26 & $56,15 \pm 17,04$ & 34 & $51,88 \pm 17,99$ & $>0,05$ \\
\hline $\begin{array}{c}\text { Nhóm ESRD chayy thânn } \\
\text { nhân tạo chù kỳ }\end{array}$ & 60 & $41,85 \pm 13,56$ & 31 & $43,26 \pm 14,33$ & 29 & $40,34 \pm 12,75$ & $>0,05$ \\
\hline p2 $^{*}$ & & $>0,05$ & & $>0,05$ & & $>0,05$ & \\
\hline
\end{tabular}


* $\mathrm{p}^{1}$ : so sánh giữa nam và nữ; $\mathrm{p}^{2}$ : so sánh giữa nhóm điều trị bảo tồn và nhóm chạy thận nhân tạo chu kỳ.

Không có sự khác biệt về tuổi giữa nam so với nữ, giữa nhóm ESRD điều trị bảo tồn so với nhóm ESRD chạy thận nhân tạo chu kỳ.

Bảng 3.2. Nồng độ AU huyết thanh của đôii tượng nghiên cứu

\begin{tabular}{|c|c|}
\hline Nhóm bệnh & Nồng độ AU huyết thanh $(\boldsymbol{\mu m o l} / \mathbf{L})$ \\
\hline Nhóm bệnh nhân ESRD điêu trị bảo tồn $(\mathrm{n}=60)$ & $490 \pm 131,6$ \\
\hline Nhóm bệnh nhân ESRD chạy thận nhân tạo chu kỳ $(\mathrm{n}=60)$ & $500,28 \pm 95,48$ \\
\hline$p$ & $>0,05$ \\
\hline
\end{tabular}

Không có sự khác biệt có ý nghĩa thống kê nồng độ AU huyết thanh giữa nhóm bệnh nhân ESRD điêuu tri bảo tồn so với nhóm bệnh nhân ESRD chay thận nhân tao chu kỳ.

Bảng 3.3. Nồng độ AU huyêt thanh theo nhóm tuổi và giới của đôi tượng nghiên cứu

\begin{tabular}{|c|c|c|c|c|}
\hline \multicolumn{3}{|c|}{ Phân nhóm đối tượng nghiên cứu } & Nông độ AU huyết & $\mathbf{p}$ \\
\hline \multirow{5}{*}{$\begin{array}{l}\text { Nhóm ESRD } \\
\text { điêu trị bảo tồn }\end{array}$} & \multirow{3}{*}{ Nhóm tuổi } & $18-40$ tuối $(n=17)$ & $473 \pm 154,34$ & \multirow{3}{*}{$<0,05$} \\
\hline & & $41-60$ tuối $(n=17)$ & $493 \pm 85,7$ & \\
\hline & & $61-80$ tuối $(n=26)$ & $499,73 \pm 143,62$ & \\
\hline & \multirow{2}{*}{ Giới } & $\operatorname{Nam}(n=26)$ & $534,46 \pm 114,5$ & \multirow{2}{*}{$<0,05$} \\
\hline & & Nũ $(n=34)$ & $456,91 \pm 135,46$ & \\
\hline \multirow{5}{*}{$\begin{array}{l}\text { Nhóm ESRD } \\
\text { chạy thâan nhân } \\
\text { tạo chu kỳ }\end{array}$} & \multirow{3}{*}{ Nhóm tuổi } & $18-40$ tuối $(n=33)$ & $524,06 \pm 96,77$ & \multirow{3}{*}{$>0,05$} \\
\hline & & $41-60$ tuối $(n=18)$ & $485,67 \pm 80,57$ & \\
\hline & & $61-80$ tuối $(n=9)$ & $442,33 \pm 100,81$ & \\
\hline & \multirow{2}{*}{ Giới } & $\operatorname{Nam}(n=31)$ & $501,97 \pm 103,93$ & \multirow{2}{*}{$>0,05$} \\
\hline & & Nữ $(n=29)$ & $498,48 \pm 87.34$ & \\
\hline
\end{tabular}

Có sự khác biệt có ý nghĩa thống kê về nồng độ $A U$ huyết thanh giữa các nhóm tuối và giữa nam so với nữ ở nhóm bệnh nhân ESRD điều trị bảo tồn nhưng không khác biệt có ý nghĩa thống kê ở nhóm bệnh nhân ESRD chạy thận nhân tạo chu kỳ.

Bảng 3.4. Tỷ lệ bệnh nhân tăng nồng độ AU huyết thanh của nhóm bệnh thận mạn giai đoạn cuối

\begin{tabular}{|c|c|c|c|c|c|c|c|}
\hline \multirow{3}{*}{ Chỉ số } & \multicolumn{7}{|c|}{ Nhóm bênh thân man giai đoan cuối } \\
\hline & \multicolumn{2}{|c|}{$\begin{array}{c}\text { Chung } \\
(n=120)\end{array}$} & \multicolumn{2}{|c|}{$\begin{array}{l}\text { Nhóm ESRD điêu trị } \\
\text { bảo tồn }(\mathrm{n}=60)\end{array}$} & \multicolumn{2}{|c|}{$\begin{array}{l}\text { Nhóm ĖSRD chạy thận } \\
\text { nhân tạo chu kỳ }(\mathrm{n}=60)\end{array}$} & $\mathrm{p}$ \\
\hline & $\mathbf{n}$ & $\%$ & $\mathbf{n}$ & $\%$ & $\mathbf{n}$ & $\%$ & \multirow[b]{2}{*}{0,05} \\
\hline $\begin{array}{l}\text { Tỷ lêt tăng nông độ } \\
\text { Aư huyết thanh }\end{array}$ & 102 & $85,0 \%$ & 50 & $83,3 \%$ & 52 & $86,7 \%$ & \\
\hline
\end{tabular}

Tỷ lệ tăng AU huyết thanh của đối tượng nghiên cứu là 85,0\%. Không có sự khác biệt có ý nghĩa thống kê về tỷ lệ tăng AU huyết thanh giữa nhóm ESRD điều trị bảo tồn và nhóm chạy thận nhân tạo chu kỳ.

Bảng 3.5. Nồng độ AU huyết thanh theo thời gian ở nhóm bệnh nhân ESRD chạy thận nhân tạo chu kỳ

Thời gian chạy thận nhân tạo chu kỳ $<1$ năm $(n=16)$ Nồng độ AU huyết thanh ( $\mu \mathrm{mol} / \mathrm{L})$ $524,38 \pm 85,78$ $\mathrm{p}$ $491,52 \pm 98,22$ $>0,05$

Không nhận thấy sự khác biệt có ý nghĩa thống kê về nồng độ AU huyết thanh với thời gian chạy thận của nhóm bệnh nhân chạy thận chu kỳ.

Bảng 3.5. Mối tương quan giữa nồng độ AU huyêt thanh với chỉ số nhân trắc, chỉ số huyêt áp và thời gian lọc máu của đôii tượng nghiên cứu

\begin{tabular}{|c|c|c|c|c|}
\hline \multicolumn{2}{|c|}{ Chỉ số } & \multicolumn{3}{c|}{ Nồng độ AU huyết thanh $(\boldsymbol{\mu m o l} / \mathbf{I})$} \\
\cline { 2 - 5 } & Chiều cao $(\mathrm{m})$ & $\mathbf{n}$ & $\mathbf{r}$ & $\mathbf{p}$ \\
\hline \multirow{3}{*}{ Chỉ số nhân trắc } & Cân nă̆ng $(\mathrm{kg})$ & 120 & 0,110 & $>0,05$ \\
\cline { 2 - 5 } & BMI $\left(\mathrm{kg} / \mathrm{m}^{2}\right)$ & 120 & 0,148 & $>0,05$ \\
\hline \multirow{2}{*}{ Huyết áp } & $\operatorname{HATT}(\mathrm{mmHg})$ & $\mathbf{1 2 0}$ & 0,086 & $>0,05$ \\
\cline { 2 - 5 } & $\operatorname{HATTr}(\mathrm{mmHg})$ & 120 & $\mathbf{0 , 4 2 3}$ & $<\mathbf{0 , 0 1}$ \\
\hline
\end{tabular}




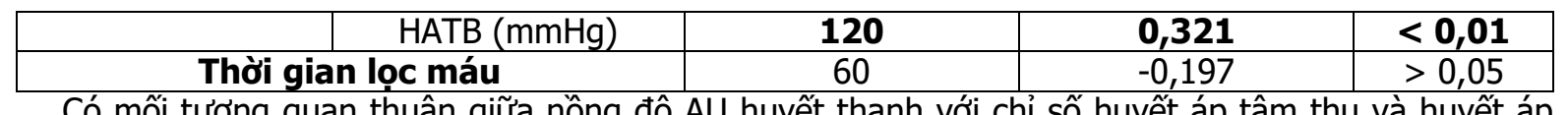

Co mối tương quan thuận giữa nồng độ AU huyết thanh với chỉ số huyết áp tâm thu và huyết áp trung bình của đối tượng nghiên cứu.

\section{BÀN LUÂ̂N}

4.1. Nông đô acid uric huyết thanh của nhóm bệnh nhân bệnh thận mạn giai đoạn cuối. Nhiều nghiên cứu đã chỉ ra rẳng $\mathrm{AU}$ là một trong những yếu tố nguy cơ tim mạc và nguy cơ tử vong ở bệnh nhân bệnh thận mạn giai đoạn cuối [5],[9]. Kết quả nghiên cứu của chúng tôi cho thây nồng độ $A U$ huyết thanh trung bình đều tăng ở 2 nhóm với giá trị là 490,0 $\pm 131,6 \mu \mathrm{mol} / \mathrm{L}$ ở nhóm bệnh thận mạn giai đoạn cuối điều trị bảo tồn và $500,28 \pm 95,48 \mu \mathrm{mol} / \mathrm{L}$ ở nhóm bênh thận mạn chạy thận chu kỳ nhưng sự khác biệt không có ý nghĩa thống kê. Nghiên cứu của Tokiko Miyaoka và cộng sự trên 551 bệnh nhân BTM giai đoạn 2-4. Độ tuổi trung bình của các đối tượng nghiên cứu là 58,5 tuổi, 59,3\% là nam giới. MLCT trung bình là $42,02 \pm 18,52$ $\mathrm{ml} / \mathrm{phút} / 1,73 \mathrm{~m}^{2}$. Ở tất cả các đối tượng, nồng độ $\mathrm{AU}$ huyết thanh trung bình là $8,1 \pm 1,35 \mathrm{mg} / \mathrm{dl}$ $(486 \pm 119,47 \mu \mathrm{mol} / \mathrm{l})$ [8].

Trong nghiên cứu này chúng tôi chia nhóm nghiên cứu theo 3 nhóm tuổi ở người trưởng thành là 18 đến 40 tuổi, 41 đến 60 tuổi và 61 đến 80 tuổi. Kết quả nghiên cứu cho thây ở nhóm bệnh nhận bệnh thận mạn giai đoạn cuối điều trị bảo tồn chỉ số nồng độ $A U$ huyết thanh có xu hướng tăng dần ở các nhóm tuổi (18-40 tuổi: $473 \pm 154,34 \mu \mathrm{mol} / \mathrm{L}$; 41-60 tuổi: $493 \pm$ 85,7 $\mu \mathrm{mol} / \mathrm{L} ; \quad 61-80$ tuổi: 499,73 $\pm 143,62$ $\mu \mathrm{mol} / \mathrm{L})$ và ở nam $(534,46 \pm 114,5 \mu \mathrm{mol} / \mathrm{L})$ lớn hơn so với nữ $(456,91 \pm 135,46 \mu \mathrm{mol} / \mathrm{L})$ sự khác biệt này có ý nghĩa thống kê $(p<0,05)$. Kết quả nghiên cứu của Kang D.H, Chen W nghiên cứu trên bệnh nhân bệnh thận mạn cũng cho nhận định tương tự [4]. Estrogen ngăn chặn lượng protein tái hấp thu urat, làm tăng đào thải acid uric qua thận, dẫn đến giảm nồng độ acid uric huyết thanh. Sự hiện diện của estrogen được cho là có thể bảo vệ phụ nữ chống lại các tổn thương ở thận.

Kết quả bảng 3.4 cho thây trong 120 bệnh nhân bệnh thận mạn giai đoạn cuối thì có tới 102 bệnh nhân tăng nồng độ AU huyết thanh chiếm $85,0 \%$. Trong đó nhóm điều trị bảo tồn là $83,3 \%$, trong nhóm thận nhân tạo chu kỳ là $86,7 \%$, tî lệ tăng $\mathrm{AU}$ huyết thanh không có sự khác biệt có ý nghĩa thống kê giữa 2 nhóm nghiên cứu $(p>0,05)$. Nghiên cứu trong nước của Nguyễn Hữu Dàng (2015) trên 42 bệnh nhân bệnh thận mạn với tỉ lệ tăng $A U$ huyết thanh ở nhóm bệnh nhân bệnh thận mạn giai đoạn $\mathrm{V}$ là $79,05 \%$ và nghiên cứu của tác giả $Y X$ Qing và cộng sự cho tỷ lệ bệnh nhân tăng AU ở giai đoạn cuối là 89,0\%, kết quả tương đương với tỷ lệ tăng $\mathrm{AU}$ huyết thanh ở nhóm bệnh thận mạn giai đoạn cuối điều trị bảo tồn của chúng tôi. Dựa vào kết quả nghiên cứu trên chúng ta thấy rằng tỷ lệ tăng $A U$ huyết thanh ở bệnh nhân bệnh thận mạn giai đoạn cuối tăng cao, mặc dù đã có những nghiên cứu chứng minh nồng độ $A U$ tăng cao sẽ làm giảm chức năng thận. Nhưng việc điều trị hạ nồng độ $A U$ huyết thanh không triệu chứng trên bệnh nhân BTM đang gây tranh cã̃i. Một cuộc khảo sát liên quan đến việc quản lý tăng AU huyết thanh không có triệu chứng ở bệnh nhân BTM của các bác sĩ thận học Nhật Bản cho thấy hầu hết các bác sĩ thận học (84$89 \%$ ) đã điêu trị tăng $A U$ huyêt thanh không triêu chứng ở bệnh nhân BTM giai đoạn 3 đến 5 để ngăn ngừa tiến triển BTM hoặc các biến cố tim mạch. Ngoài $r a$, họ khuyến cáo rằng liêuu pháp hà urat bằng dược lý nên được cân nhẳc cho những bệnh nhân có nồng độ $A U$ trong huyết thanh $>8,0 \mathrm{mg} / \mathrm{dl}(480 \mu \mathrm{mol} / \mathrm{L})$. Tuy nhiên, phương pháp này không được khuyến khích ở Hoa Kỳ và Châu Âu, vì việc sử dụng liệu pháp điều trị tăng $A U$ huyết thanh không triẹu chứng không thích hợp đã được báo cáo là có liên quan đến nguy cơ đáng kể về da và tác dụng phụ toàn thân đe dọa tính mang.

4.2. Các mối liên quan của nồng độ acid uric huyết thanh ở đối tượng nghiên cứu. Xét hệ số tương quan ở bảng 3.5 cũng cho thấy không có mối tương quan giữa nồng độ $A U$ huyết thanh với chỉ số cân nặng, chiều cao và chỉ số BMI ở nhóm bệnh nhân bệnh thận mạn điều trị bảo tồn và lọc máu. Khác với kết quả nghiên cứu của chúng tôi, nghiên cứu của tác giả Marie Doualla và cộng sự (2018) [3] trên 200 bệnh nhân bệnh thận mạn do tăng huyết áp cho thấy nồng độ $A U$ huyết thanh tương quan thuận với chỉ số BMI ở nhóm bệnh nhân nghiên cứu. Giải thích cho sự khác nhau này có thể do đối tượng nghiên cứu của tác giả Marie Doualla số người béo phì có tỷ lệ cao, trong khi nghiên cứu của chúng tôi chỉ có 5 bệnh nhân (4,167\%) số bệnh nhân có chỉ số BMI > 25 và không có bệnh nhân nào có chỉ số BMI > 30 . 
Tăng huyết áp là biến chứng tim mạch thường gặp nhất trong bệnh lý thận mạn. Tắng huyết áp được xác định là yếu tố góp phần làm tăng tốc độ tiến triển của bệnh lý thận mạn cũng như làm tăng nguy cơ các biến cố tim mạch khác. Xét hệ số tương quan bảng 3.5 nhận thấy có mối tương quan thuận có ý nghĩa thống kê giữa nồng độ $A U$ huyết thanh với các chỉ số huyết áp tâm thu $(r=0,423, p<0,01)$ và huyết áp trung bình $(r=0,321, p<0,01)$ ở nhóm bệnh nhân bị bệnh thận mạn. Không nhận thấy có mối tương quan giữa nồng độ AU huyết thanh với chỉ số huyết áp tâm trương ở nhóm bệnh nhân bị bệnh thận mạn $(r=0,088)$. Nghiên cứu của tác giả Marie Doualla và cộng sự (2018) trên 200 bệnh nhân người Mỹ bị bệnh thận do tăng huyết áp cũng cho thấy nồng độ $A U$ huyết thanh ở nhóm tăng huyết áp tăng cao hơn nhóm không tăng huyết áp [3]. Ngày càng có nhiều bằng chứng cho thấy nồng độ $A U$ đóng một vai trò trong sự phát triển của tăng huyết áp. AU có thể gây tăng huyết áp bằng cách làm trung gian các con đường gây viêm trong cơ trơn mạch máu, ức chế nitric oxide nội mô và hoạt hóa hệ thống renin-angiotensin. Mặt khác, tăng huyết áp làm tăng sức cản mạch thận, giảm lưu lượng thận, làm tăng tái hấp thu urat.

Về mối liên quan giữa nồng độ $A U$ với thời gian chạy thận nhân tạo chù kỳ ở nhóm bệnh nhân ESRD chạy thận nhân tạo chu kỳ, kết quả nghiên cứu cho thây chỉ số trung bình nồng độ AU huyết thanh ở nhóm bệnh nhân có thời gian loc máu dưới 1 năm là $524,38 \pm 85,78 \mu \mathrm{mol} / \mathrm{l}$ và chỉ số trung bình nồng độ $\mathrm{AU}$ huyết thanh của nhóm bệnh nhân có thời gian lọc máu từ 1 năm trở lên là 491,52 \pm 98,22 $\mu \mathrm{mol} / \mathrm{l}$. Chúng tôi nhận thấy nồng độ $\mathrm{AU}$ huyết thanh có xu hướng giảm khi thời gian lọc máu kéo dài (giảm 32,86\%), nhưng sự khác biệt này không có ý nghĩa thống kê $(p>0,05)$. Điều này được củng cố thêm ở kết quả bảng 5 cho thấy nồng độ $A U$ huyết thanh có mối tương quan nghịch yếu với thời gian lọc máu $<1$ năm $(r=-0,175, p>0,05)$ và thời gian lọc máu $\geq 1$ năm ( $r=-0,197, p>$ $0,05)$. Nghiên cứu của Marie Doualla cùng cộng sự [3] trên 144 bệnh nhân bệnh thận mạn giai đoạn cuối chạy thận chu kỳ trung bình 2 lần/1 tuần với thời gian duy trì lọc máu trung bình là 3 năm cho thây rằng lọc máu đơn thuần làm giảm đáng kể lượng $A U$ huyết thanh $(p<0,001)$, nhưng mức giảm này là vừa phải. Kết quả này có sự khác biệt với nghiên cứu của chúng tôi, để giải thích cho sự khác biệt này chúng tôi nhận thấy thời gian duy trì lọc máu trung bình trong nghiên cứu của tác giả Marie Doualla lớn hơn so với mốc thời gian chúng tôi chọn trong nghiên cứu.

\section{KẾT LUÂN}

- Nồng độ acid uric huyết thanh nhóm bảo tồn là $490,0 \pm 131,6 \mu \mathrm{mol} / \mathrm{L}$, nhóm chạy thận chu kỳ là $500,28 \pm 95,48 \mu \mathrm{mol} / \mathrm{L}$, sự khác biệt không có ý nghĩa thống kê $(p>0,05)$.

- Tỷ lệ bệnh nhân bệnh thận mạn giai đoạn cuối có tắng acid uric huyết thanh là $85,0 \%$. Ở nhóm điêuu trị bảo tồn là $83,3 \%$ và ở nhóm chạy thận nhân tạo chu kỳ là $86,7 \%$, sự khác biệt không có ý nghĩa thống kê ( $p>0,05)$.

- Nồng độ acid uric huyết thanh tăng dần theo nhóm tuổi và nam giới cao hơn nữ giới trong nhóm bệnh nhân bệnh thận mạn điều trị bảo tồn $(p<0,05)$.

- Có mối tương quan thuận mức độ vừa giữa nồng độ acid uric huyết thanh với chì số huyết áp tối đa $(r=0,423 ; p<0,01)$ và huyết áp trung bình $(r=0,321 ; p<0,01)$

- Không nhận thây mối tương quan giữa nồng độ acid uric huyết thanh với chỉ số BMI và thời gian lọc máu.

\section{TÀI LIÊU THAM KHẢO}

\section{Nguyễn Đat Anh, Nguyễn Thị Thu Hương} (2013). "Cảc xét nghiệm thường quy áp dụng trong thực hành lâm sàng". Nhà xuất bản Y học.

2. Corry DB, Eslami P, Yamamoto K, Nyby MD, Makino H, Tuck ML (2008). "Uric acid stimulates vascular smooth muscle cell proliferation and oxidative stress via the vascular renin-angiotensin system". J Hypertens. 2008 Feb;26(2):269-75.

3. Doualla M, Halle MP, Moutchia J, Tegang S, Ashuntantang G (2018). "Determinants of hyperuricemia in non-dialysed chronic kidney disease patients in three hospitals in Cameroon". BMC Nephrol. 2018;19(1):1-9.

4. Kang D-H, Chen $\mathbf{W}$ (2021). "Uric acid and chronic kidney disease: new understanding of an old problem". Semin Nephrol. 2011 Sep;31 (5): 447-52.

5. Kim K, Go S, Son HE, Ryu JY, Lee H, Heo NJ, et al (2020). "Association between Serum Uric Acid Level and ESRD or Death in a Korean Population". J Korean Med Sci. 2020 Jul; 35(28):e254.

6. Levin A, Stevens PE (2014). "Summary of KDIGO 2012 CKD Guideline: Behind the scenes, need for guidance, and a framework for moving forward". Kidney Int [Internet]. 2014;85(1):49-61.

7. Murea M, Tucker BM (2019). "The physiology of uric acid and the impact of end-stage kidney disease and dialysis". Semin Dial. 2019 Jan;32(1):47-57.

8. Miyaoka T, Mochizuki T, Takei T, Tsuchiya K, Nitta K (2014). "Serum uric acid levels and longterm outcomes in chronic kidney disease". Heart Vessels. 2014 Jul;29(4):504-12.

9. Zawada AM, Carrero JJ, Wolf M, Feuersenger A, Stuard S, Gauly A, et al (2020). "Serum Uric Acid and Mortality Risk Among". Kidney Int Reports [Internet]. 2020;5(8):1196-206. 